19. Sirak S. V., Sletov A. A., Pereverzev R. V. Eksperimentalnoe primenenie poristogo titana pri otkrytom sinus liftinge. (Experimental use of porous titanium at open sinus elevation). Palliativnaya meditsina $i$ reabilitatsyia - Palliative medicine and rehabilitation. 2012:1:55-57.

20. Sirak S. V., Shchetinin E. V., Sletov A. A. Subantralnaya augmentaciya poristim titanom v eksperimente i klinike (Subantral augmentation with porous titanium in the experiment and clinic). Stomatologiya - Stomatology. 2016:95(1):55-58.

21. Widera D., Zander C., Heidbreder M. et al. Adult palatum as a novel source of neural crest-related stem cells. Stem Cells 2009;27:1899-1910.

22. Widera D., Grimm W.-D., Moebius J. M. Highly efficient neural differentiation of human somatic stem cells, isolated by minimally invasive periodontal surgery. Stem Cells Dev. 2007;16:447-460.

About authors:

Grimm Wolf-D., Professor, MD, PhD, MSc, Department of Dental Medicine, Faculty of Health, University

of Witten/Herdecke, Germany; Department of Stomatology, Stavropol State Medical University, Russian Federation;

tel.: +49230252971; e-mail: prof_wolf.grimm@yahoo.de

Fritsch Tilman, MD, PhD, Professor of Implantology:

tel.: +498651/64622; e-mail: tilmanf@hotmail.com

Giesenhagen Bernd, MD, PhD, Professor of Implantology;

tel.: +49561/40085362; e-mail: b.giesenhagen@gmx.de

Marco Alexander, MD, msc, Implantologist;

tel.: +492339911160, fax: +492339911162; e-mail: team@ph-zahnaerzte.de

Aybazov Magomet, Doctor of Agricultural Science, Professor, Head of Department for Sheep Breeding; tel.: $+7(8652) 717033$

Adamchik Anatoly, Candidate of Medical Science, Associate Professor, Head of Dept Therapeutic Stomatology; tel.: +7(8652)370795; e-mail: adamchik1@mail.ru

\title{
PROPERTIES OF DEVELOPED NIOSOMAL FORMS OF ANTI-CANCER SUBSTANCES N-HYDROXY-2-(2-(NAPHTHALEN-2-YL)-1H-INDOL-3-YL)-2- PHENYLACETAMIDE IN TREATMENT OF GLIOBLASTOMA
}

\author{
Bazikov I. A. ${ }^{1}$, Aksenov A. V. ${ }^{2}$, Maltsev A. N. ${ }^{1}$, Selimov M. A. ${ }^{2}$, Kornienko A. V. ${ }^{3}$, \\ Aksenov N. A. ${ }^{2}$, Aksenova I. V. ${ }^{2}$, Bazikov F. I. ${ }^{4}$ \\ 1 Stavropol State Medical University, Russian Federation \\ 2 North-Caucasis Federal University, Stavropol, Russian Federation \\ 3 Texas State University, San Antonio, United States of America \\ ${ }^{4}$ Charles University, Prague, Czech Republic
}

\section{СВОЙСТВА РАЗРАБОТАННОЙ НИОСОМААЬНОЙ ФОРМЫ

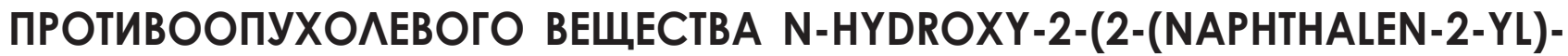 1H-INDOL-3-YL)-2-PHENYLACETAMIDE ААЯ АЕЧЕНИЯ ГАИОБААСТОМЫ}

\author{
И. А. Базиков ${ }^{1}$, А. В. Аксенов ${ }^{2}$, А. Н. Мальцев ${ }^{1}$, М. А. Селимов ${ }^{2}$, А. В. Корниенко \\ Н. А. Аксенов ${ }^{2}$, И. В. Аксенова ${ }^{2}$, Ф. И. Базиков 4 \\ ${ }^{1}$ Ставропольский госуаарственный меАицинский университет, Российская ФеАерация \\ 2 Северо-Кавказский фелеральный университет, Ставрополь, Российская ФеАерация \\ 3 Техасский госуаарственный университет, Сан-Антонио, США \\ ${ }^{4}$ Карлов университет, Прага, Чешская Республика
}

The physical properties of niosome form of anti-cancer substances Ax7 was studied. Samples of substances scanned in atomic forced microscope. Analyzing the results showed the middle size of niosomes with incapsulated antitumor substance is $100 \mathrm{~nm}$. Microviscosity of niosomes is low and elasticity is high, what ensures the passage of drug through the small capillaries and intercellular space. Silicone niosomes easily integrated into the plasma 
membrane. This improves transport of $A x 7$ substances into the cell. The results of obtained study of prototype drug physical properties, demonstrated its high ability to transport anticancer agents Ax7 to glioblastoma.

Key words: glioblastoma, anti-cancer substances Ax7, niosomes, atomic force microscopy

Исследовали физические свойства препарата разработанной ниосомальной формы противоопухолевого вещества Ax7. Образцы препарата сканировали на атомно-силовом микроскопе NTEGRA Life (HT-MДT). Измерение микровязкости оболочки ниосом проводили методом латеральной диффузии гидрофобного флуоресцентного зонда пирена. Флуоресценцию измеряли с помощью спектрофлуориметра PЧ-5301PC (Shimadzu) (Япония). Анализ результатов показал, что средний размер ниосом с инкапсулированным противоопухолевым веществом составил 100 нм. Это указывает на наноразмерности используемых для доставки противоопухолевого вещества Ax7, ниосом кремнийорганической природы. Ниосомы обладают низкой микровязкостью и высокой эластичностью, что обеспечивает прохождение сквозь мелкие капилляры и межклеточные пространства. Кремнийорганические ниосомы легко встраиваются в плазматические мембраны. Это улучшает транспорт вещества Aх7 в клетку. Определены параметры флуоресценции противоопухолевого вещества Ах7, которые составили $\lambda$ ex= 322 нм и $\lambda \mathrm{em}=422$ нм. Результаты, полученные при исследовании физических свойств опытного образца препарата, продемонстрировали его высокую способность для доставки противоопухолевого вещества Ах7 к глиобластоме.

Ключевые слова: глиобластома, противоопухолевое вещество Ах7, ниосомы, атомно-силовая микроскопия

A synthesized compound of $\mathrm{N}-h y d r o x y-2-(2-(n a p-$ hthalen-2-yl) - 1H-indol-3-yl)-2-phenylacetamide (Ax7) in vitro showed high cytotoxic activity against cancer cells $[1,2]$. However the limitation of therapeutic use of anti-cancer substances is its toxicity to normal tissues $[3,5]$. A promising approach to overcome low bioavailability and systemic toxicity is the application of drug-loaded nanosized drug carriers, such as polymeric nanoparticles, liposomes, dendrites and micelles $[6,7,8]$. Use of such carriers has several advantages compared to systemic chemotherapy, it can modulate the pharmacokinetics of existing drugs, and it may be useful to enhance delivery of anticancer agents to target sites. One of the new ways to reduce the toxicity of anticancer agents is its capsulation in niosomes. Niosomes are the microscopic lamellar structures, are formed on the admixture of non-ionic surfactant of the alkyl or dialkyl polyglycerol ether class and cholesterol, with subsequent hydration in aqueous media [9]. They resemble liposomes in their architecture and can be used as an effective alternative to liposomal drug carriers [10]. Niosomes are a promising vehicle for drug delivery, and since they are non-ionic, they are less toxic and improve the therapeutic index of drugs by restricting their action to target cells. The characteristics of the vesicle formulation are variable and controllable. Altering vesicle composition, size, lamellarity, trapped volume, surface charge and concentration can control vesicle characteristics. The vesicles may act as a depot, releasing the drug in a controlled manner. Niosomes are osmotically active, stable and increase the stability of the entrapped drug. They improve oral bioavailability of poorly absorbed drugs and enhance skin penetration. Niosomal dispersion in an aqueous phase can be emulsified in a non-aqueous phase to regulate the delivery rate of drug and administer normal vesicle in an external non-aqueous phase. Niosomes have been proposed for a number of potential therapeutic applications, i.e., as immunological adjuvants [11], anticancer and anti-infective drug targeting agents $[12,13]$, carriers of anti-inflammatory drugs $[4,14]$ and as diagnostic imaging agents [10]. In addition, niosomes are versatile carrier systems and can be administered through various routes. Particular efforts have been aimed at using niosomes as effective transdermal drug delivery systems [15,
16]. We have developed a method of reducing the toxicity of anticancer drugs by encapsulating them in a silicone niosomes having a size of 100 nanometers as effective transdermal drug delivery systems. This technique enables to smooth the introduction of the therapeutic dose and to increase and improve the effectiveness of the drug due to the deposit of the drug and an inability to communicate with the formed elements of the blood. In addition, the incorporation of anticancer drugs in silicone niosomes having a large lipophilic effect, allowing them not to penetrate into the healthy tissues, penetrating only through a defective capillaries of the skin tumor and thereby improve their therapeutic effects $[3,4]$.

The aim of the work was to study the physical properties of the niosome form of anti-cancer substances Ax7.

Material and Methods. To study the size of niosomes used atomic force microscopy. Sample preparation was carried out as follows: pre-prepared samples (blank niosomes encapsulated by $A \times 7$, empty silver coated niosomes and encapsulated by Ax7 coated silver niosomes were dissolved in ethanol and then stirred until complete dissolution and were applied in the form of several drops on freshly cleaved mica plate, then it was dried at a room temperature for 1 hour. Further, the plates with fixed specimens were scanned in the atomic force microscope, brand NTegra Life (NT-MDT). According to the obtained data on the topography of the surface, through the use of application of the programming tools (NovaPX), a histogram of average size particles to the scanned area of the substrate was constructed. All scanned fields had a size $5 \times 5 \mathrm{mkm}$. The modes of all scanning samples were maintained in the same parameters. Scanning was performed in tapping mode, the cantilever HA NC Etalon.

Microviscosity measurement of niosome was performed by lateral diffusion of the hydrophobic fluorescent probe of pyrene. Of determination of microviscosity is based on the formation of excimers (active dimers) of piren in the lipid environment $[17,18,19]$. Piren fluorescence was measured by a spectrofluorimeter RF-5301PC (Shimadzu) (Japan). The effectiveness of the inclusion of the drug in niosomes was determined by the formula:

$$
\mathbf{E I}=\mathbf{C}_{\text {nios }} / \mathbf{C}_{\text {overall }} \times \mathbf{1 0 0} \text {. }
$$

Where $\mathrm{El}$ - the effectiveness of inclusion. C nios - the concentration of the drug in niosomes. C overall - the total drug concentration in the solution. 
The results were processed statistically using the Student t-test (the significance of differences was considered at $p<0.05$ ).

Results and Discussion. The histogram of the first sample showed that scanned using atomic force microscopy prototypes nanocontainers silicone nature (niosomes) have dimensions of about $100 \mathrm{~nm}$ (Fig. 1A).

The presence of PEG (polyethylene glycol moiety) determines the stability of the hydrophilic environments and protection from attack by cells of the reticuloendothelial system.

Further [2] and its penetration into the lipid bilayer miviscosite membranes can be reduced. Since there are published data whereby cytostatics increased membrane fluidity. Previously it has been shown that increas-

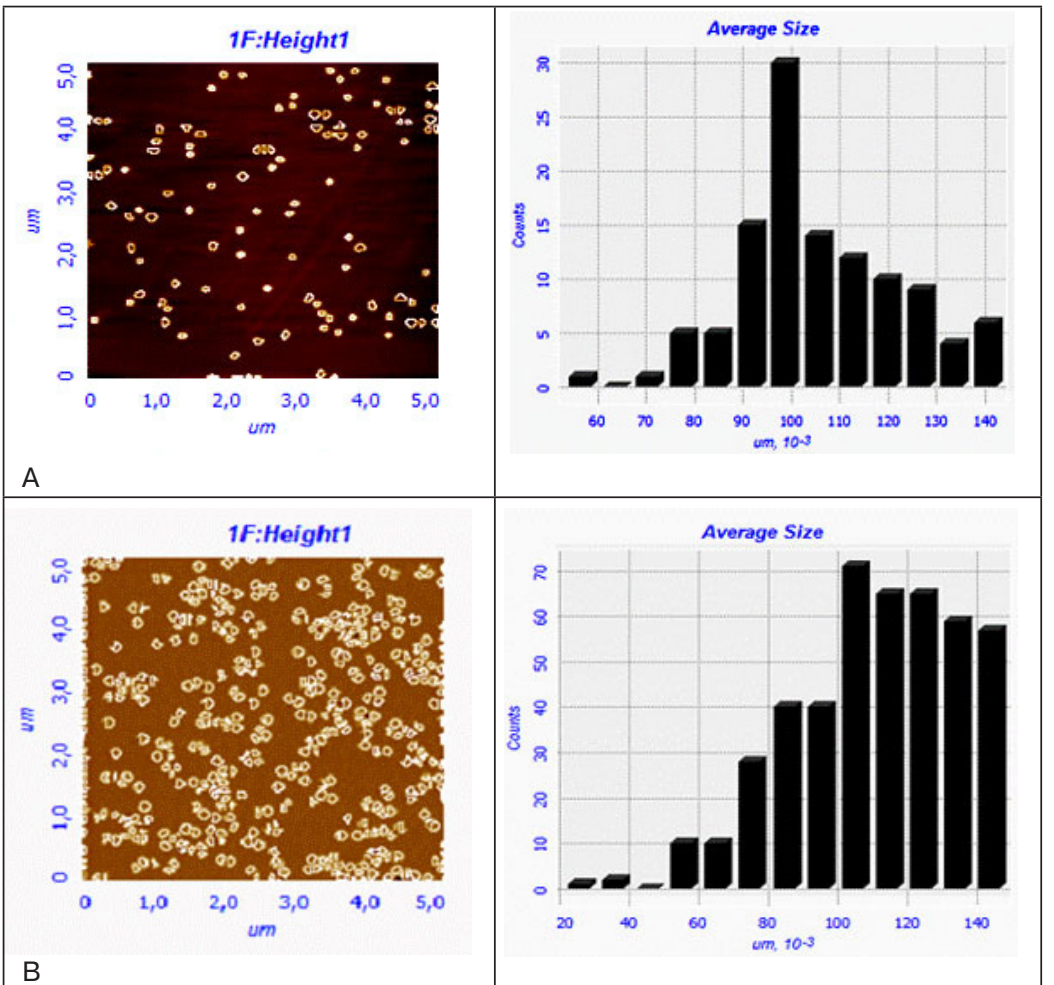

Fig. 1. The Atomic force microscopy niosomes and histograms of average size: A - intact niosomes; B - niosomes encapsulated substance Ax7 ing concentrations of 2-aryl-2-(3-indolyl) acetohydroxamic acid relative GI50 2-3 times causes dramatic accumulation of large vacuoles, which ultimately leads to disruption of membrane integrity and cell death. The mechanism of this process remains unclear [1, 2]. According to the literature with increasing flow membrane becomes permeable to water and other small hydrophilic molecules, increasing the speed of lateral diffusion of integral proteins [20]. If the active center integral protein performs a function that, exclusively located in the hydrophilic part, the change in lipid yield is probably not too much to affect the activity of the protein. But if the protein performs the transport function and the transport component crosses the membrane, the properties of the lipid phase change can lead to a significant change in the rate of transport of substances across membranes [18, 19]. In our case displayed above the phenotypic characteristics of the impact on the cancer cells of 2-aryl-2-(3-indolyl) acetohydroxamic acids may be associated with such not apoptopic types of cell death is programmed necrosis, autophagy, paraptoz, metuozis, pay attention to the part scientific community as an alternative strategy to fight tumors resistant to apoptosis. The dependence of the observed

Encapsulation in niosomes anticancer agents increased their dimensions. Data characterizing the 2 sample showed a predominance of particles of 100 to $140 \mathrm{~nm}$ (Fig. 1B). The substance is poorly soluble in water and thus occurs in a shell embedding niosomes. This increases the size of niosomes.

We have studied the possibility of using pyrene to characterize the physical properties of niosomes. As a result of this work showed that when incorporating pyrene into niosomes maximum at fluorescence 460$470 \mathrm{~nm}$, which is associated with the appearance of the excimer fluorescence form. In our case, an increase of the excimer fluorescence form indicates that niosomes have lower microviscosity compared with cell membrane. The presence of organic silicon polymer in niosomes makes them more stable and osmotically active.

Identified changes in the physical properties of niosome in our opinion are due to the fact, the length of $\mathrm{Si}-\mathrm{O}$ bond length $\mathrm{C}-\mathrm{C}$, so the molecule is $\mathrm{PEG}-12$ of dimethicone is more elastic then phospholipids used in the formation of vesicles (liposomes), and is capable of forming vesicles without significant energy efforts. Si bond length 1,6 A (bond length of surfactants analogues $\mathrm{C}-\mathrm{C} 1.4 \mathrm{~A}$ ), the bond angle $\mathrm{Si}-\mathrm{O}-\mathrm{Si}$ is 130 degrees, 109 degrees opposed to the $\mathrm{C}-\mathrm{C}-\mathrm{C}$, which leads to increased elasticity and stability [3, 4].

Communication $\mathrm{Si}-\mathrm{O}-\mathrm{Si}$ rotates and therefore also has a high elasticity. Due to this, when embedding niosomes membrane phospholipid bilayer fluidity increases. phenotypic effect of the concentration of 2-aryl-2-(3-indolyl) acetohydroxamic acids allows the selective effect on cancer cells (Fig. 2).

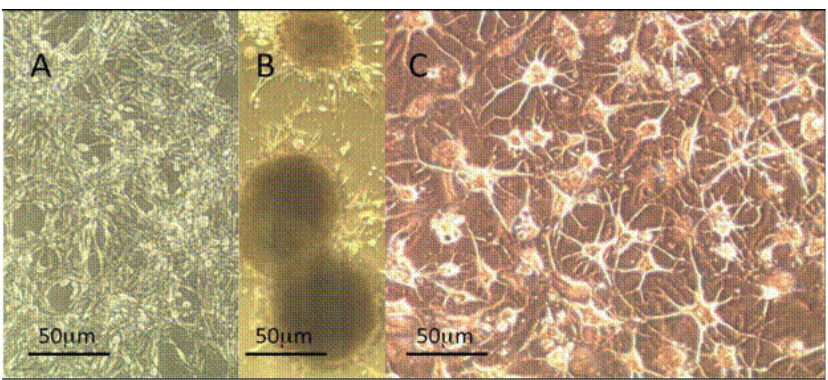

Fig. 2. Redifferentiation cancer cell phenotype astrocyte U87 3aaa: 3-day glioblastoma cancer cells (A); after application of cells $A \times 7$ substance for 3 days (B); the cells after application Ax7 substance for 33 days at a dose of $7 \mathrm{uM}$ (C)

Analysis of the intensity ratio $I_{372} / I_{393}$ indicates a change in the polarity of the environment of monomeric pyrene probe molecules in the interaction of erythrocyte membranes niosomal form of the drug. Polarity anular lipids varies in a similar manner. However, these changes are more pronounced, in comparison with free lipids. This may be explained by the interaction of the drug with membrane Bellamy and cause the development process redifferentiating damaged cells.

We have studied the ability to do the of fluorescence anti-cancer substances Ax7. Experimentally established 
wavelengths of excitation and emission, for which made $E_{e x}=$ $322 \mathrm{~nm}$ and $E_{\mathrm{em}}=422 \mathrm{~nm}$. When the concentration of $A x 7$ in niosomes increases in fluorescence intensity increases too. Based on the results of calibration curve for the study of the degree of incorporation Ax7 in niosomes was constructed.

The effectiveness of the inclusion of the drug in niosomes is more than $80 \%$, which we believe is due to lipophilic substances and used as a solvent, 1, 2- propylene glycol.

Conclusions. The average particle size analysis using atomic force microscopy prototype drug showed

\section{References}

1. Aksenov A. V., Smirnov A. N., Magedov I. V., Reisenauer M. R., Aksenov N. A. Activity of 2-Aryl-2(3-indolyl) acetohydroxamates against Drug-Resistant Cancer Cells. J. Med. Chem. 2015;58:2206-2220.

2. Aksenov A. V., Smirnov A. N., Aksenov N. A., Bijieva A. S., Aksenova I. V., Rubin M. Benzimidazoles and benzoxazoles via the nucleophilic addition of anilines to nitroalkanes. J. Org. Biomol. Chem. 2015;13:42894295.

3. Bazikov I. A. New antimicrobial niosomes gel of silicone nature. Journal Problems of Medical Mycology. 2015; 17(2):41.

4. Bazikov I. A., Chekrygina E. V., Klimanvich I. V., Maltsev A. N. Development of a pharmacetical anticancer gel based on doxorubicin and silicone nanotechnology. Meditsinskii Vestnik Severnogo Kavkaza. - Medical News of North Caucasus. 2015;10(2):163-166.

5. Bazikov I. A., Beyer E. V., Lukinova V. V., Maltsev A. N. Comparative evaluation of acute toxicity of doxorubicin and its normal form. Meditsinskii Vestnik Severnogo Kavkaza. - Medical News of North Caucasus. 2015;10(4):403-406

6. Bansal S. S., Goel M., Aqil F., Vadhanam M. V., Gupta R. C. Advanced drug delivery systems of curcumin for cancer chemoprevention. Cancer Prevent. Res. 2011;4:1158-1171

7. Mishra B., Patel B. B., Tiwari S. Colloidal nanocarriers: a review on formulation technology, types and applications toward targeted drug delivery. Nanotechnol. 2010;6:924.

8. Oerlemans C., Bult W. Bos M. Storm G., Nijsen J. F. W., Hennink W. E. Polymeric micelles in anticancer therapy: targeting, imaging and triggered release. Pharm. Res. 2010;27:2569-2589.

9. Malhotra M., Jain N. K. Niosomes as drug carriers. Indian Drugs 1994;31:81-86.

10. Ijeoma F., Uchegbu I. F., Suresh P. V. Non-ionic surfactant based vesicles (niosomes) in drug delivery. Int. J. Pharm. 1998;172:33-70. that mostly dominated niosomes size of $100 \mathrm{~nm}$. This indicates that the niosomes of the silicone nature used to deliver antitumor agents Ah7 and facilitate passage of the drug through the small intercellular spaces and capillaries. Fluorescence of niosomal form anti-cancer substances $A x 7$ amounted $\lambda e x=322 \mathrm{~nm}$ and $\lambda e m=422$ $\mathrm{nm}$. These results will be used for a detailed study of pharmacokinetics anticancer substances $A x 7$ in preclinical studies of transdermal efficiency for the treatment of glioblastoma.

11. Jain S., Singh P., Mishra V., Vyas S. P. Mannosylated niosomes as adjuvantcarrier system for oral genetic immunization against Hepatitis B. Immunol. Lett. 2005;101:41-49.

12. Balasubramaniam A., Kumar V. A., Pillai K. S. Formulation and in vivo evaluation of niosome-encapsulated daunorubicin hydrochloride. Drug Dev. Ind. Pharm. 2002;28:1181-1193

13. Gude R. P., Jadhav M. G., Rao S. G., Jagtap A. G. Effects of niosomal cisplatin and combination of the same with theophylline and with activated macrophages in murine B16F10 melanoma model. Cancer Biother. Radiopharm. 2002; 17:183-192.

14. Shahiwala A., Misra A. Studies in topical application of niosomally entrapped Nimesulide, Journal of Pharmacy and Pharmaceutical Sciences: A Publication of the Canadian Society for Pharmaceutical Sciences. Journal of Pharmacy and Pharmaceutical Sciences. 2002;5:220225.

15. Choi M. J., Maibach H. I. Liposomes and niosomes as topical drug delivery systems. Skin. Pharmacol. Physi. 2005;18:209-219.

16. Barry B. W. Novel mechanisms and devices to enable successful transdermal drug delivery. Eur. J. Pharm. Sci. 2001:14:101-114.

17. Vladimirov Yu. A., Proskurnina E. V. Novel mechanisms and devices to enable successful transdermal drug delivery. Journal Advances of Biological Chemistry. 2009;49:341-388.

18. Vladimirov Yu. A., Dobretsov G. E. Fluorescent Probes in the study of biological membranes. M.: «Nauka»; 1980.

19. Dobretsov G. E. Fluorescent Probes in the study of cells, membranes and lipoproteins. M.: «Nauka»; 1989

20. Shalashnay E. V., Goroshinskaya I. A., Nerodo G. A. Guskova E. A., Surikova E. I. Investigation of the effect of chemotherapy on the level of endogenous intoxication, the intensity of free radical oxidation and membrane unit of blood cells of patients with recurrent cervical cancer ah experiments in vitro. Siberian Journal of Oncology. 2008;2(26):11-16.

\section{About authors:}

Bazikov Igor, MD, Professor, Head of Department of microbiology; tel.: +7(8652)352475; e-mail: bazikov@list.ru

Aksenov Alexander, Professor, Doctor of Chemistry, Head of Department of chemistry; tel.: +79187430255; e-mail: k-bochem-ord@stavsu.ru

Kornienko Alexander, PhD, Associate Professor, Department of Chemistry and Biochemistry; tel.: +7(512)2453632; e-mail: a_k76@txstate.edu

Bazikov Filipp, student of Bachelor of Molecular Biology department of the Faculty of Natural Sciences; tel.: +420778049505; e-mail: filippbazikov@gmail.com

Aksenova Inna, Doctor of chemistry, Professor, Department of Chemistry Institute of living systems ; tel.: +7(8652)330856; e-mail: inna-aksenova00@rambler.ru 